\title{
Physiochemical characteristics of soil in tropical sal (Shorea robusta Gaertn.) forests in eastern Nepal
}

\author{
Shishir Paudel $¥ *$ and J ay P Sah $\$$ \\ $\dagger$ Brookfield International College, Kathmandu, Nepal \\ \$Central Department of Botany, Tribhuvan University, Kathmandu, Nepal; \\ Present address- Southeast Environmental Research Center, Florida International University, Miami, FL 33199, USA \\ * Towhom correspondenceshould beaddressed. E-mail: paude84@yahoo.com
}

\begin{abstract}
The physiochemical properties of soils of two different types of forests (pure Shorea robustaand mixed Shorea robusta) were analyzed. Soil samples were collected from both types of forest and analyzed for texture, $\mathrm{pH}$, organic matter, humus content, water holding capacity, nitrogen, phosphorous and potassium. In both the pure and mixed forest, soil was sandy loam $(60.12 \%$ and $50.58 \%$ sand, $28.59 \%$ and $35.24 \%$ silt and 11.12 and $22.41 \%$ clay, respectively). The pH value was lower in pure forest (4.33) than in the mixed forest (5.26), and so were phosphorus and water holding capacity. The higher values of humus, organic matter, nitrogen and potassium $(7.34 \%, 2.42 \%$, $0.117 \%, 267.73 \mathrm{~kg} / \mathrm{ha}$, respectively) were found in pure forest. The higher levels of soil nutrients in the pure forest were due partly to reduction in the loss of top soil and partly to the increased supply of nutrients in the form of leaf litter and biomass from the larger number of sal trees and their saplings.
\end{abstract}

Key words: Shorea robusta, soil texture, nitrogen, soil pH, Udayapur

Him J Sci 1(2): 107-110

URL: www.himjsci.com/issue2/ salforest

Received: 16 Apr 2003

Accepted after revision: 20 June 2003

\section{Introduction}

Forest soils influence the composition of the forest stand and ground cover, rate of tree growth, vigor of natural reproduction and other silviculturally important factors (Bhatnagar 1965). For instance, growth of Shorea robusta (sal) and other tree species, such as Terminalia alata and Syzygium aumini, in tropical forests is highly influenced by nitrogen, phosphorus, potassium, and soil $\mathrm{pH}$ (Bhatnagar 1965). Physiochemical characteristics of forest soils vary in space and time due to variations in topography, climate, physical weathering processes, vegetation cover, microbial activities, and several other biotic and abiotic variables. Vegetation plays an important role in soil formation (Chapman and Reiss 1992). For example, plant tissues (from aboveground litter and belowground root detritus) are the main source of soil organic matter (OM), which influences physiochemical characteristics of soil such as $\mathrm{pH}$, water holding capacity (WHC), textureand nutrient availability (Johnston 1986). Nutrient supply varies widely amongecosystems (Binkley and Vitousek 1989), resulting in differences in plant communitystructureand production (Ruessand Innis 1977, Chapin et al. 1986). Organic matter supplies energy and cell building constituentsfor mostmicroorganisms (Allison 1973) and isa critical factor in soil fertility (Brady 1984).

The vegetation zones in Nepal clearly reflect edaphic variations (Bhatta 1981). TheTerai region ischaracterized byalluvial soil, which is transported bytheriver systems. River deposits more sand and silt than clay in the flood plains of the Terai that support the dense forests of sal and other valuable timber trees. However, the sal forests are in a degraded state in terms of both density as well as ground vegetation because of indiscriminate cutting, recurring forest fire and uncontrolled grazing. In fact, more than half of the tropical soil in the world is highly weathered, leached and impoverished, and thereforemechanismsto conservenutrient in the ecosystem are important (Sanchez 1976, Jordan 1985). The objectiveof thepresent study wasto document thephysiochemical characteristics (WHC; pH; soil texture; N, P, K, OM and humus content) of soil in two separate and dissimilar sal forests: a pure stand of S. robusta managed by the local community, and a mixed S. robusta forest managed by the government.

\section{Materials and methods}

Study area

The study was carried out in April and May 1998 in Ward 6 of Triyuga Municipality in Udayapur district of eastern Nepal (86 $6^{\circ}$ $87^{\circ} 10^{\prime}$ E, $26^{\circ} 39^{\prime}-27^{\circ} 11^{\prime} \mathrm{N}$ ), and comprised thepure S. robusta Sanua Sukanahi community forest as well as the mixed Banke Danda national forest. The elevation of the site ranges from 210 to $250 \mathrm{~m}$ asl. The soils are non-sticky sandy loam because the geological formation of the district lies in the Siwalik zone (Nepal District Profile1997). Though thestudyareahas atropical monsoon climate and receives a great deal of rain, the area seems somewhat arid because most of the rainfall flows away quickly as surface run-off, allowing thesoil to dry quickly. Theseareideal conditionsfor sal (S. robusta), which grows poorly in water logged soil (Stainton 1972).

\section{Soil sampling}

Soil was taken from $15 \mathrm{~cm}$ deep cores. It was collected from 30 randomly distributed sites in each of the pure and mixed forests. Thecollected soil sampleswere packed in polythenebagsand taken to the laboratory for analysis. Soil analyses were performed at the Central Department of Botany, Tribhuvan University, and theNepal Agriculture Research Council (NARC), Kathmandu. Soil texture was determined by the hydrometer method (PCARR 1980) and the texture group was determined by means of a texturetriangle(USDA system). Organic matter and humuscontent weredetermined using 
the methods described in PCARR (1980). Total nitrogen content was determined by means of the Kjeldalel method. Phosphorus was determined using the Truog method; potassium content by flame photometer; and soil $\mathrm{pH}$ by the potentiometric method, using a digital $\mathrm{pH}$ meter and sampling soil and water in a 1:1 ratio (PCARR 1980). Humus content and WHC werecalculated by using the following formula (cf Zobel et al. 1987).

$$
\begin{aligned}
& \text { Humus content }(\%)=\frac{\text { Weight of humus }}{\text { Weight of soil }} \times 100 \\
& \text { Water holding capacity }(\%)=\frac{\begin{array}{c}
\text { Water retained by the } \\
\text { soil at saturation }
\end{array}}{\text { Weight of dry soil }} \times 100
\end{aligned}
$$

Data analysis

To find the relationships between the parameters of soils of these forests, the correlation coefficient was calculated following the formula used by Pearson (1957).

$$
\frac{\sum \mathrm{xy}-\frac{\sum \mathrm{x} \cdot \sum \mathrm{y}}{\mathrm{n}}}{\sqrt{\left(\sum \mathrm{x}^{2}-\frac{\left(\sum \mathrm{x}\right)^{2}}{\mathrm{n}}\right)\left(\sum \mathrm{y}^{2}-\frac{\left(\sum \mathrm{y}\right)^{2}}{\mathrm{n}}\right)}}
$$

\section{Results}

Vegetation of thestudy area was dominated by theS. robusta. Both forests had similar types of plant species composition. The pureS. robusta was forest composed predominantly of S. robusta, in association with Adina cordifolia, Schleichera oleosa, Swida oblonga, Semecarpusanacardium, and other species. In themixed S. robusta forest, S. robusta and Terminalia alata were equally dominant. Other associated species included Syzygium cumini, Bombax ceiba, Acacia catechu, Schleichera oleosa, and Semecarpus anacardium.

Both forests had sandy loam type of soil texture. Thesoil of pure S. robusta forest was composed of sand $(60.12 \% \pm 3.59 \%)$, silt( $28.59 \% \pm 3.18 \%$ ), and clay $(12.24 \%+1.62 \%)$; whiletheproportions for the mixed S. robusta forest were $50.58 \% \pm 5.84 \%, 35.24 \% \pm 4.54 \%$, and $22.41 \% \pm 3.20 \%$, respectively (Figure 1).

Soil in both forests was acidic. It was more acidic in the pureS. robusta forest ( $\mathrm{pH}=4.33 \pm 0.39$ ) than in themixed S. robusta forest (5.26 \pm 0.58$)$ (Figure 2). The soil in mixed S. robusta forest had higherWHC (49.80\% $\pm 6.30 \%)$ than that in pureS. robusta forest $(43.03 \% \pm 3.02 \%)$.

The humus content of the soil in the two forests was not noticeably different: the valuewasonly slightly higher in thepureS. robusta forest $(7.34 \% \pm 1.47 \%)$ than in the mixed S. robusta $(5.5 \% \pm$ 0.99\%) forest (FIGURE 2).

Theaverage organic matter content in thesoil of thepure S. robusta forest was $2.42 \% \pm 0.39 \%$, compared to $1.74 \% \pm 0.31$ in the mixed S. robusta forest (Figure 2).

Themean soil nitrogen content in both forests was more or less similar, slightly higher in pure S. robusta forest $(0.117 \% \pm 0.01 \%)$ than in mixed S. robusta forest $(0.111 \% \pm 0.01 \%)$ (Figure 3).

Themean value of availablephosphorus in the soil of the pure S. robusta forest was $76.64 \pm 4.95 \mathrm{~kg} / \mathrm{ha}$, slightly less than the $79.29 \pm 3.92 \mathrm{~kg} /$ ha found in mixed S. robusta forest (Figure 3). The mean value for potassium was higher in the pureS. robusta forest than that in the mixed S. robusta forest, available potassium in the soil of theS. robusta forest was $267.73+29.93 \mathrm{~kg} / \mathrm{ha}$, compared with
$233.86+18.43 \mathrm{~kg} / \mathrm{ha}$ in the mixed S. robusta forest was (Figure 3).

The correlation analysis among the different soil parameters showed that the $\mathrm{pH}$ was negatively correlated with organic matter $(r=-0.311)$ and nitrogen $(r=-0.422)$, whereas there was positivecorrelation between $\mathrm{pH}$ and all other parameters such as humus content, water holding capacity, phosphorus and potassium content (Table 1). However, none of these correlations werefound statisticallysignificant.

Organic matter was slightly negatively correlated with potassium ( $r=-0.052)$ and WHC ( $r=-0.030)$, while it was slightly positively correlated with nitrogen, phosphorusand humus content. However, these correlations were not found statistically significant either. Nitrogen showed significant negative correlation with phosphorus $(r=-0.610)$ and positivecorrelation with potassium ( $r$ $=0.903$ ). It also showed positive correlation withWHC and negative correlation with humus content. Phosphorus showed significant positive correlation with potassium ( $r=0.519)$.

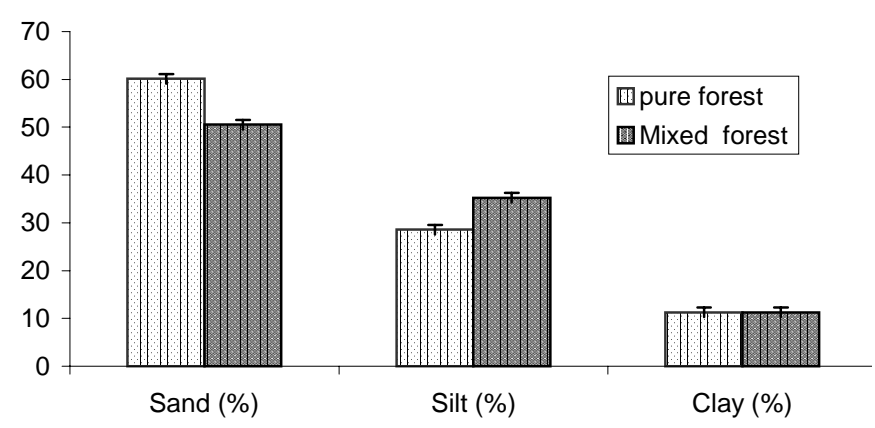

FIGURE 1. Soil texture in the forest

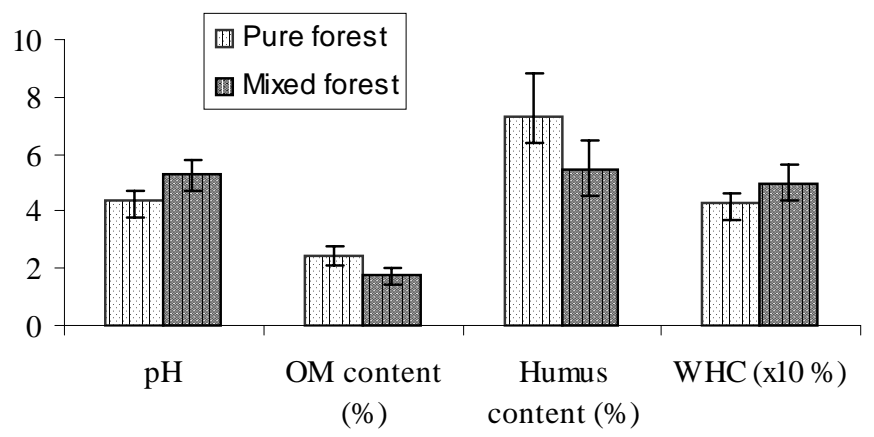

FIGURE 2. Different soil parameters

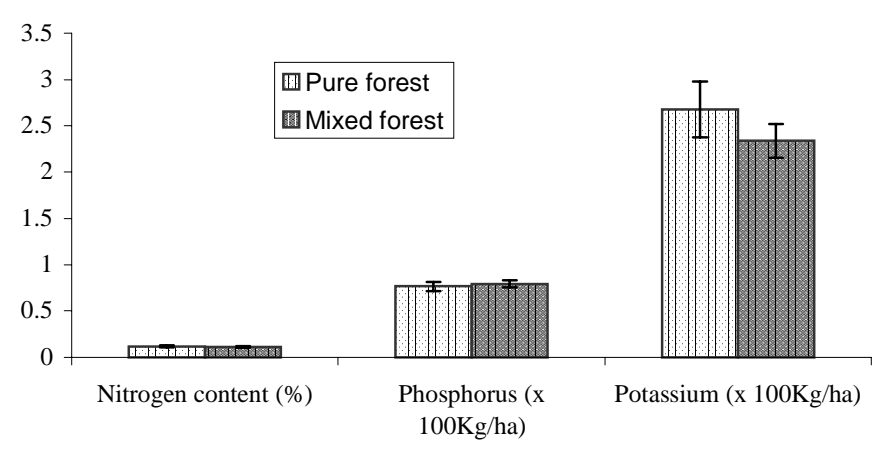

FIGURE 3. Different soil parameters 


\section{Discussion}

On the basis of vegetation composition and dominance of different plant species, forests were categorized into pure and mixed S. robusta forests. The pure S. robusta forest (managed by the local community) was highly dominated by S. robusta, whilethe mixed S. robusta forest (government managed, with free access for local people), was heterogenous and equally dominated by S. robusta and Terminalia alata. Other major associated species were Semecarpus anacardium, Adina cordifolia, Syzygium cumini, Bombax ceiba and Acacia catechu.

Soil texture in both the forests of the study area was of the sandy loam type, suitable for good sal regeneration and high quality trees (Gupta 1951). Thissandy loam texture is very common in the Terai, and in Siwalik and Dun valleys, all of which support dense sal forests and other valuabletimber trees (Shah 1999). The supply of water to plants usually is greater as the texture becomes finer (Black 1968). Soil texturealso affects the nutrient supply of the soil. The present resultissimilar to thefinding of Shrestha(1997) in Chitrepani, Sigdel (1994) in Royal Chitwan National Park (RCNP), Rana et al. (1988) and Gupta and Shukla (1991) in sal forests in India. This may be due to the similar type of forest vegetation, i.e., S. robusta dominated forest.

Soils in the forests were acidic in nature. Shrestha (1992) reported that in the Terai most of the soils are acidic. However, in the present study pure S. robusta forest soil was found to be more acidic than that of mixed S. robusta forest. The $\mathrm{pH}$ range in the present study was lower than the values reported by Sigdel (1994) in Royal Chitwan National Park (5.90-6.42), byKarki (1999) in Koshi Tappu Wildlife Reserve (6.4-7.1), or by Singh and Singh (1985) in S. robusta dominant central Himalaya forests (6.7-6.8). This may be due to local environmental factors such as aspect, rainfall, and vegetation composition. However, thevaluesobserved in thisstudy were more or less similar to those reported by Singh and Singh (1989). They reported a pH range of 4.5-5.5 in the sal forest and concluded that thisrange is propitiousfor sal saplinggrowth. Good sal regeneration areas have low pH in soils (Bhatnagar 1965). The finding of higher acidity in the sites is consistent with other observations (Banerjee et al. 1986, Singh et al. 1987). Soils with higher $\mathrm{pH}$ generally have poorer capacity for regeneration (Suoheimo 1995). Thelow pH valuein the presentstudy area may be due to the continuous decomposition of surface litter over six years. The lower $\mathrm{pH}$ in the pureS. robusta forest than in themixed S. robusta forest is probably due to higher number of sal trees and their saplings (Bhatnagar 1965), and the accumulation of leaf litter as well. The acidic nature of the soil at our study site may be attributed to the high rainfall, which is sufficient to leach basic cations from the surface horizons of the soils. Similar result was reported by Miller (1965).

Humus content was more or less similar in both forests,

TABLE 1. Correlation coefficient among different soil parameters

\begin{tabular}{lllllll}
\hline & $\mathbf{P H}$ & $\mathbf{O M}$ & $\mathbf{N}$ & $\mathbf{P}$ & $\mathbf{K}$ & $\mathbf{W H C}$ \\
\hline $\mathbf{O M}$ & -0.311 & & & & & \\
$\mathbf{N}$ & -0.422 & 0.356 & & & & \\
$\mathbf{P}$ & 0.196 & 0.262 & -0.610 & & & \\
$\mathbf{K}$ & 0.210 & -0.052 & 0.903 & 0.519 & & \\
WHC & 0.197 & -0.030 & 0.104 & 0.330 & -0.225 & \\
Humus & 0.163 & 0.015 & -0.125 & 0.063 & -0.314 & -0.241
\end{tabular}

$\mathrm{OM}=$ Organic matter, $\mathrm{N}=$ Nitrogen, $\mathrm{P}=$ Phosphorus, $\mathrm{K}=$ Potassium, WHC $=$ Water holding capacity as was organic matter content. Thelatter ranged from 1.74 to $2.42 \%$, comparable to the 1.74-2.33 range that, according to Suoheimo (1995), is indicative of low soil fertility. Brady (1984) mentioned that the higher soil organic matter occurred more commonly in cooler than warmer climates such as that of our study area. This may explain the occurrence of relatively low organic matter content in the soil despite the fact that litter had been accumulating over six years, especially in the pure S. robusta forest. Out of these two studied sites, pure S. robusta forest had higher organic matter content than the mixed S. robusta forest which may be because of more litter accumulation and decomposition in the former. Tamhane et al. (1964) mentioned that decomposing litter adds organic matter to the soil. It was seen that local people frequently visit the mixed S. robusta forest to collect forest products because in the pureS. robusta forest restrictions have been imposed on the exploitation of forest products. While, organic matter in the present study area was lower than the value (1.8-4\%) reported from the forests in Riyale (Shrestha 1996), but within the range (0.23-1.8\%) reported by Sigdel (1994) for Royal Chitwan National Park. Aweto (1981) reported that organic matter content increases with the maturation of forest. The mixed S. robusta forest is more mature, and might therefore be expected to contain more organic matter, than that of thepureS. robusta forest, but our data does not confirm this expectation, probably because the pure S. robusta forest had been protected for the previous six years, and litter collection had not been asintensiveas in the mixed forest, and also due to thelow organic input from the vegetation cover in the mixed S. robusta forest.

The value of WHC for both forests ranged from 43.03 to $49.80 \%$. According to Bhatnagar (1965), theWHC of soils from sal regeneration areas is higher. WHC in the present study area was higher than that in the Pinus roxburghii forest (9\%) and in Oak forest (17\%) in Garhwal Himalaya (Sah et al. 1994). Despite the higher organic matter and humus content in the pure S. robusta forest than in the mixed S. robusta forest, theWHC value was less in the former, probably because of the coarser soil texture; the pure S. robusta forest had more sand than the mixed S. robusta forest.

The nitrogen content of soil did not differ significantly in the two forests, and was similar to the values reported in other forests such as Chitrepani (0.04-0.09\%) (Shrestha 1997). The value of soil nitrogen was less than the value reported from theforests in Nagarkot (0.18-0.28\%; Juwa 1987), in Namchi, Sikkim (0.57\%; Gangopadhayaya et al. 1992) and in the Royal Chitwan National Park (0.13\%; Sigdel 1994). The fact that the nitrogen content in the soil was relatively low (according to the soil fertility rating system developed by NARC, 1998/1999) was probably due to the dominance of S. robusta. According to Bhatnagar (1965), there is low nitrogen content in good sal dominant and regeneration areas. In the floodplains, sandy loam soil is deficient in nitrogen (Sah 1997). The low nitrogen content in soil at our study site may have been due to the continuous losses through leaching and run-off (Allen 1964).

Our two study forests had high phosphorus ratings, according to the soil fertility rating system, NARC (1998/99). The soil in the pure S. robusta forest had higher phosphorus content than that in themixed S. robusta forest; higher than the22.59-44.28 $\mathrm{kg} /$ hareported in the Riyaleforest (Shrestha 1996), and higher than the $3-4 \mathrm{~kg} / \mathrm{ha}$ in the Nagarkot forest (Juwa 1987). However, it was very close to the value reported for the Chitrepani forest (Shrestha 1997). It was coincided with thefindings of Bhatnagar (1965).

Potassium content washigher in thepureS. robusta forest than in the mixed S. robusta forest. The value varied from 233.86 $\mathrm{kg} / \mathrm{ha}$ to $267.73 \mathrm{~kg} / \mathrm{ha}$. According to Bhatnagar (1965), potassium in soil is higher in good sal regeneration areas. The sites of the presentstudy had a higher rateof regeneration of sal, probably due 
to the presence of higher proportion of potassium. The value was within the range of $86.40-262.8 \mathrm{~kg} / \mathrm{ha}$ as reported in S. robusta forest in Chitrepani (Shrestha 1997), but less than that (329.57-399 kg/ ha) reported in Koshi Tappu Wildlife Reserve (Karki 1999) and higher than thevalue $(41.01-87.79 \mathrm{~kg} / \mathrm{ha}$ ) reported in two sal forests in the hills of Kavreplanchowk (Pant 1997).

The forest soils in our study area contain significant quantities of all thenutrients exceptnitrogen. According to the soil fertility rating system of NARC (1998/99), phosphorus had a high value and potassium a medium value, while nitrogen had a low rating value. Overall, the pure S. robusta forest had higher soil nutrients than the mixed S. robusta forest, probably due to higher organic matter input from the tree cover as it had over six years' litter decomposition.

\section{Conclusion}

Soils in the forests were sandy loam. There was low nitrogen, high phosphorus and medium potassium content. Soil characteristics seem to have strong influence on the vegetation of the present study area and vice versa. The pure S. robusta forest had relatively good soil characteristicsas compared to themixed S. robusta forest. On the whole the nutrient-poor status of the soils found under these forests represents the degraded status of the forest. Degradation maybepartlynatural and partly deliberately induced by the local people for fulfilling their household needs through variousstrategies. Hence, the conservation of sal forestsisan urgent need. The proper management of the forests will increase the quality of soils and the forest.

\section{References}

Allen SE. 1964. Chemical aspects of heather burning.J Appl Ecol 1: 347-67

Allison FA. 1973. Soil organic matter and its rolein crop production. Amsterdam Elsevier

Aweto AO. 1981. Secondary succession and soil fertility restoration in Southwestern Nigeria II: Soil fertility restoration. J Ecol 69: 609-14

BanerjeeSK, SB Singh, SNath and SP Banerjee. 1986. Comparison of somephysicochemical properties of soils of varying age plantations of Cryptomeria japonica. J Ind Soc Soil Sci 34: 357-61

Bhatnagar HP. 1965. Soils from different quality sal (S. robusta) forests of Uttar Pradesh. Trop Ecol 6: 56-62

BhattaDD. 1981. Nepal Himalayaand change. In: Laal JS(ed), Himalaya: Aspects of change. New Delhi: Oxford University Press. p 253-77

Binkley D and PM Vitousek. 1989. Soil nutrient availability. In: Pearey RW, J Ehleringer, HAMooney and PW Rundel (eds), Plant physiological ecology: Field methodsand instrumentation. London: Chapman and Hall. p 75-96

Black CA. 1968. Soil plant relationship, 2nd ed. New Delhi:Wiley Eastern

Brady NC. 1984. Thenatureand properties of soils. New York: Mac Millan

Chapin FSH, KVan Cleveand PM Vitousek. 1986. Thenature of nutrient limitation in plant communities. Am Nat 127: 148-58

Chapman JL and MJ Reiss. 1992. Ecology: Principlesand applications. Cambridge: CambridgeUniversity Press. $294 \mathrm{p}$

Gangopadhyaya SK, PK Das, SNath, SP Banerjee and SK Banerjee. 1992. Characteristics of some lower and middle hill soil of south Sikkim forests. Sikkim, Namchi. Ind For 118: 662-71

Gupta OP and RP Shukla. 1991. Thecomposition and dynamics of associated plant communities of sal plantations. Trop Ecol 32(2): 296-309

Gupta RS. 1951. Recurrence in drought conditions in mortality in sal forests of Uttar Pradesh. I Ind Bot Soc 40(1): 25-33

Johnston AE. 1986. Soil organic matter; effects on soil and crops. Soil UseManage 2: $97-105$

Jordan CF. 1985. Nutrient cycling in tropical forest ecosystems. Chichester: John
Wiley

Juwa GB. 1987. Soil and sites of selected plantation areasin theKathmandu project area of thehill forestry devel opment project. Kathmandu: Forest Research Division, Department of Forestry and Research, HMGN. 66p

Karki S. 1999. Ecological study of riverine forest in Koshi Tappu Wildlife Reserve (KTWR) [thesis]. Kathmandu: Central Department of Botany, Tribhuvan University. $56 \mathrm{p}$

Miller CE. 1965. Soil reaction and limingsoil fertility. NewYork:John Wiley and Sons Inc. $436 \mathrm{p}$

NARC. 1998/99. Annual report 1998/99. Kathmandu: Nepal Agricultural Research Council, Soil Science Division. 112p

Nepal District Profile. 1997. Adistrict wisesocio-economic profilealongwith a comprehensivenational profile. Kathmandu: National Research Associates

Pant A. 1997. A comparativestudy of vegetation and natural regeneration of two hill forests: Community forest and degraded forest [thesis]. Kathmandu: Central Department of Botany, Tribhuvan University. $57 \mathrm{p}$

PCARR. 1980. Standard method of analysisfor soil, plant tissuewater and fertilizer Los Banos (Laguna): Farm, Resourceand Systems Research Division, PhilippineCouncil for Agriculture and Research. 194p

Pearson K. 1957. Thegrammar of science. New York: Meridian Books, Inc. 453p

Rana BS, SP Singh and RP Singh. 1988. Biomass and productivity of central Himalayan sal (S. robusta) forest. Trop Ecol 29(2): 1-5

RuessjO and GSInnis. 1977. A grassland nitrogen flow simulation model. Ecology 58: 348-57

Sah JP. 1997. Koshi tappu wetlands: Nepal'sramsar site. Kathmandu: IUCN Nepal. $254 p$

Sah VK, AK Saxena and V Singh. 1994. Seasonal variation in plant biomass and net primary productivity of grazing lands in theforestzone of Garhwal Himalaya. Trop Ecol 35: 115-31

Sanchez PA. 1976. Propertiesand management of soil in thetropics. NewYork:John Wiley. $618 p$

Shah R. 1999. Soils: Their problemsand management. In: MajupuriaTC (ed), Nepal: Nature'sparadise Kathmandu: HillsidePress Ltd. p 64-8

Shrestha A. 1992. Physical and chemical properties of soil in Nepal.J For Inf Nep 3(4): $27-29$

ShresthaS. 1996. Ecological study of degraded, regenerating and natural forestsin RiyaleKavrepalanchowk district, central Nepal [thesis]. Kathmandu: Central Department of Botany, Tribhuvan University. $127 p$

Shrestha R. 1997. Ecological study of natural and degraded forests of Chitrepani, Makawanpur district, Nepal [thesis]. Kathmandu: Central Department of Botany, Tribhuvan University. $113 p$

Sigdel ER. 1994. Physico-chemical properties of soil in Royal Chitwan National Park [thesis]. Kathmandu: Central Department of Botany, Tribhuvan University. $49 p$

Singh B, SNath, PK Das, SB Singh and SK Banerjee. 1987. Soil characteristics under introduced Cryptomeria japonica (Dhupi) in Darjelling Himalayan Region. Ind For 113(3): 191-201

Singh SP and JSSingh. 1989. Ecology of central Himalayan forest with special referenceto sal forest ecosystem. In: Singh JS and B Gopal (eds), Perspectivein ecology. New Delhi:Jagamander Book Agency. p 193-232

Singh SP and JSSingh. 1985. Structureand function of the forestecosystem of central Himalayas: Implication for management. In: Singh JS (ed), Environmental regeneration in Himalayas. Nainital: The Central Himalayan Environment Association and Gyanodya Prakashan. p. 83-113

Stainton JDA. 1972. Forests of Nepal. London: Camelot Press Ltd. $181 \mathrm{p}$

SuoheimoJ. 1995. Natural regeneration potential of mixed sal (S. robusta) forestsin Nepal, Vol II. FMUDP working paper no 18. Kathmandu: National ForestDivision, Department of Forests, Ministry of Forest and Soil Conservation, HMGN

TamhaneRV, DP Motiramani,YP Bali and RL Donahue. 1964. Soils: Their chemistry and fertilityin tropical Asia. New Delhi: Prentice Hall of India Private Limited

Zobel DD, PKJha, MJ Behm and UKRYadav. 1987. A practical manual for ecology. Kathmandu: RatnaBook Distributors.149p

\section{Acknowledgements}

Wearethankful to IFRI for providing financial support and to thestaff for their companionship in thefield study; and to the Central Department of Botany, Tribhuvan University, and NARC for providing laboratory facilitiesto analyze soil. 